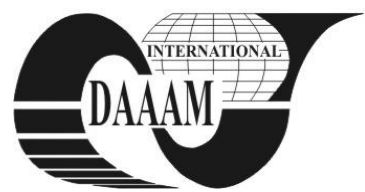

Annals of DAAAM for 2011 \& Proceedings of the 22nd International DAAAM Symposium, Volume 22, No. 1, ISSN 1726-9679 ISBN 978-3-901509-83-4, Editor B. Katalinic, Published by DAAAM International, Vienna, Austria, EU, 2011 Make Harmony between Technology and Nature, and Your Mind will Fly Free as a Bird

\title{
EFFECT OF HIGH FEED MILLING ON THE MICROSTRUCTURE AND MICROHARDNESS OF SURFACE LAYER
}

\author{
PETRU, J[ana]; CEP, R[obert]; GREPL, M[artin] \& PETRKOVSKA, L[enka]
}

\begin{abstract}
The paper is dealing by the evaluation of microstructure and microhardness of surface layer after high feed milling. The quality of surface layer is one of the main important outputs of cutting process. Experiment was realized on the universal 5 axis CNC cutting centre, like testing cutting tool material was used high alloy high speed steel ASP 2023 Cutting speeds and cutting feed rates were variable parameters and cutting depth was constant parameter. Study of surface layer properties helps to evaluate influence of machining.
\end{abstract}

Key words: machining, microhardness, surface layer, microstructure, high feed milling

\section{INTRODUCTION}

High feed machining is a difficult term to define due to a number of decisive factors including the properties of the material being machined, the availability of suitable tool materials, wide range of speeds and feeds of available machine tools (Erdel, 2003).

High speed machining reaches increase in material removal, quality of machined surface and life of a tool by the significant increase of cutting speed with decreased cross section of a shaving and lowered cutting force (Shaw, 2005).

High relative speed of the shaving with respect to the front area of a tool, together with the new quality of a cutting edge, increases the cutting process amount of heat, which is removed with the shaving, lowers heat and mechanical loading on the tool and increases its useful life. Reduction of heat flows that go into the tool, frame of a machine and the machined part gives us increase in the machined part accuracy and quality of its surface (Grzesik, 2008).

\section{MACHINE TOOL, MATERIAL AND CUTTING PARAMETERS}

For experimental work was used a cutter from the Kennametal Europe GmbH company. The cutter F3AJ1800ADN30 is a carbide three cutting edges shank cutter with the diameter $18 \mathrm{~mm}$ and helix rise of $30^{\circ}$. This cutter is suitable for high speed machining due to its rigid body and design with satisfactorily large tooth gap.

The tool is also suitable for finish cutting. Primarily the cutter is intended for machining of $\mathrm{P}, \mathrm{M}, \mathrm{K}$ and $\mathrm{S}$ materials, and alternatively for machining of $\mathrm{N}$ materials.

The material for experimental part was select ASP 2032 with following specification in table 1 .

\begin{tabular}{|l|l|l|l|l|l|l|}
\hline Elements & C & Cr & Mo & W & Co & V \\
\hline $\begin{array}{l}\text { Weight } \\
{[\%]}\end{array}$ & 1,28 & 4,1 & 5,0 & 6,4 & - & 3,1 \\
\hline
\end{tabular}

Tab. 1. Specification of material ASP 2032

ASP 2023 is a high alloy high speed steel, manufactured powder metallurgically using the ASP Process. Material ASP 2023 is suitable for operations under extremely demanding conditions. Material ASP 2023 can be work as follows: machining; polishing; plastic forming; electrical discharge machining; welding.

Delivery hardness was supplied soft annealed max. $260 \mathrm{HB}$. Heat in a protective atmosphere to $850-900^{\circ} \mathrm{C}$, hold for 3 hours, slow cool at $10^{\circ} \mathrm{C} / \mathrm{h}$ down to $700^{\circ} \mathrm{C}$, then air cooling.

For the experimental work was tested hardness HBW 2.5/187.5 of material in the Vitkovice testing center (VTC.30) with hardness tester EmcoTest. At drafting measurement of hardness was proceeded from standard for hardness test of Brinell CSN EN ISO 6506.

The microstructure evaluation of basic material was effected on luminous metallographical microscope NEOPHOT 21 at $500 x$ magnification. Figure 1 shows secondary carbides in temper martensite base of material ASP 2023.

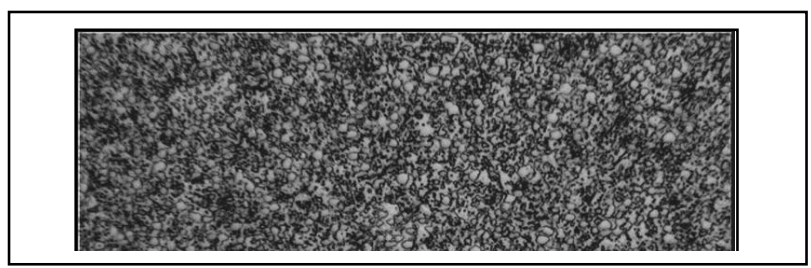

Fig. 1. The metallographical detail of material ASP 2023 (magnified 500x, etching agent Nital 1\%)

The major variable in the experiment are cutting conditions. The axial cutting depth was determined with regard to application of this technology during finish to:

- Cutting depth $\mathrm{a}_{\mathrm{p}}=0.25 \mathrm{~mm}$,

- Effective width of cuts $a_{e}=16 \mathrm{~mm}$,

- Diameter of milling cutter $\mathrm{D}=18 \mathrm{~mm}$,

- Feed on the tooth $\mathrm{f}_{\mathrm{z}}=0.33 \mathrm{~mm}$.

The following cutting conditions were chosen for experimental work on the universal 5 axis $\mathrm{CNC}$ cutting centre Deckel Maho:

- Feed rates $\mathrm{v}_{\mathrm{f}} 10,15,20 \mathrm{~m} \cdot \mathrm{min}^{-1}$,

- Revolutions n 10000, 15000, $20000 \mathrm{~min}^{-1}$,

- Cutting speeds $\mathrm{v}_{\mathrm{c}} 565.5,848.2,1131.0 \mathrm{~m} \cdot \mathrm{min}^{-1}$.

\section{MEASUREMENT \\ OF \\ SURFACE MICROHARDNESS}

The measurement of surface microhardness HV0.1 was done on a automatic measuring apparatus - the AM 43 LECO hardness tester in the Mechanical laboratory of the Faculty of Mechanical Engineering of VŠB-Technical University of Ostrava. The load of the measuring was $100 \mathrm{~g}$.

The indenter was the Vickers diamond pyramid. Measured values of depths of hard layer $h_{z}$ refere that during the cutting speed approximately $\mathrm{v}_{\mathrm{c}} 565.5 \mathrm{~m} \cdot \mathrm{min}^{-1}$ (feed rate $\mathrm{v}_{\mathrm{f}} 10 \mathrm{~m} \cdot \mathrm{min}^{-1}$ ) the widest depths of hard layer $h_{z}$ were achieved. The depth of hard layer improves when we exceed this speed. 
The narrowest depths of hard layer $h_{z}$ are of course achieved during the cutting speed $\mathrm{v}_{\mathrm{c}} 1131.0 \mathrm{~m} \cdot \mathrm{min}^{-1}$ (feed rate $\left.\mathrm{v}_{\mathrm{f}} 20 \mathrm{~m} \cdot \mathrm{min}^{-1}\right)$. Figure 2 shows the photograph of comprehensive view of the machined surface 2. Cutting conditions for surface 2 were select: feed rate $\mathrm{v}_{\mathrm{f}} 15 \mathrm{~m} \cdot \mathrm{min}^{-1}$, revolution $\mathrm{n} 15000 \mathrm{~min}^{-1}$, cutting speed $\mathrm{v}_{\mathrm{c}} 848.2 \mathrm{~m} \cdot \mathrm{min}^{-1}$.

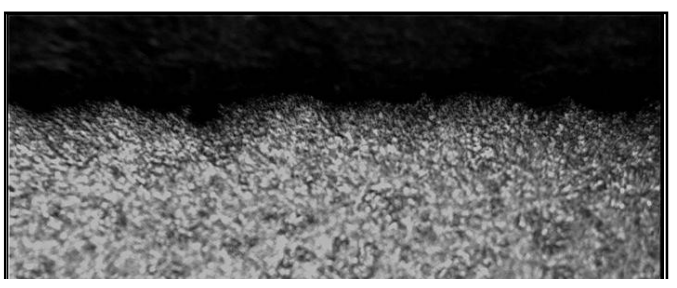

Fig. 2. The sample of machined surface 2 (magnified 200x, etching agent Nital $1 \%$ )

\section{INFLUENCE OF CUTTING PARAMETERS ON MICROHARDNESS MACHINED SURFACE}

The widest depths of hard layer $h_{\mathrm{z}}$ were achieved at cutting speed $v_{c} 565.5 \mathrm{~m} \cdot \mathrm{min}^{-1}\left(\mathrm{v}_{\mathrm{f}} 10 \mathrm{~m} \cdot \mathrm{min}^{-1}\right)$. The depth of hard layer is lower with increasing cutting speed.

Figure 3 shows influence of cutting parametres on microhardness values of material ASP 2023 for three machined surface, that is:

- Surface 1 (feed rate $\mathrm{v}_{\mathrm{f}} 10 \mathrm{~m} \cdot \mathrm{min}^{-1}$, revolution $10000 \mathrm{~min}^{-1}$, cutting speed $\left.\mathrm{v}_{\mathrm{c}} 565.5 \mathrm{~m} \cdot \mathrm{min}^{-1}\right)$,

- Surface 2 (feed rate $\mathrm{v}_{\mathrm{f}} 15 \mathrm{~m} \cdot \mathrm{min}^{-1}$, revolution $15000 \mathrm{~min}^{-1}$, cutting speed $\left.\mathrm{v}_{\mathrm{c}} 848.2 \mathrm{~m} \cdot \mathrm{min}^{-1}\right)$,

- Surface 3 (feed rate $\mathrm{v}_{\mathrm{f}} 20 \mathrm{~m} \cdot \mathrm{min}^{-1}$, revolution $20000 \mathrm{~min}^{-1}$, cutting speed $\left.\mathrm{v}_{\mathrm{c}} 1131.0 \mathrm{~m} \cdot \mathrm{min}^{-1}\right)$.

Depth mark of measuring 1 was measured in half of hard layer machined surface. Other values of microhardness HV0.1 (depth mark of measuring 2 up to 10) were continuous measured with measuring pitch $250 \mu \mathrm{m}$ in the depth of material in vertical direction on surface.

Improvement in the microhardness values were demonstrated during high speed machining. The mentioned theoretical assumptions were confirmed (Skopeček \& Vodička, 2005).

Material microhardness deslines with increased cutting speed (feed rate) to the feed rate values around $\mathrm{v}_{\mathrm{f}} 10$ to $20 \mathrm{~m} \cdot \mathrm{min}^{-1}$ and then remains constant.

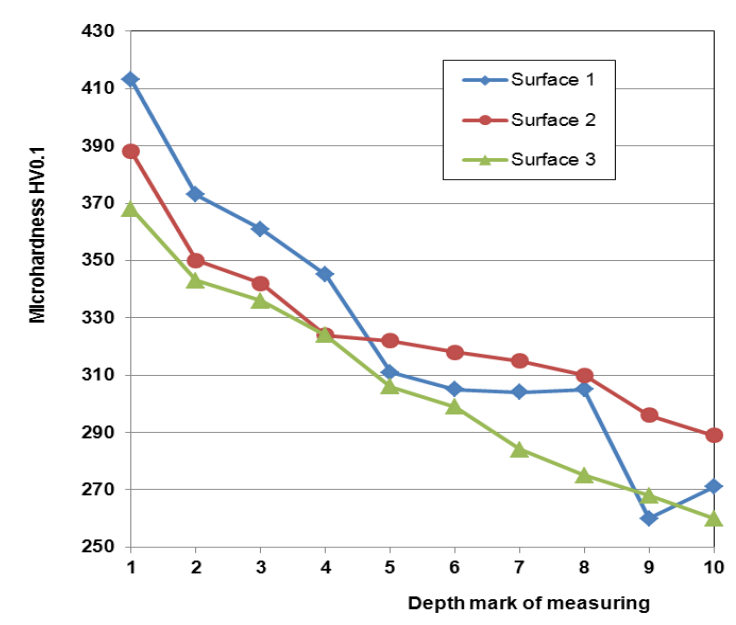

Fig. 3. The microhardness values of material ASP 2023 for variables cutting parametres of high feed cutting
During cutting with the three-teeth cutter the highest microhardness values were achieved at cutting speed $\mathrm{v}_{\mathrm{c}} 565.5 \mathrm{~m} \cdot \mathrm{min}^{-1}$ (feed rate $\mathrm{v}_{\mathrm{f}} 10 \mathrm{~m} \cdot \mathrm{min}^{-1}$ ), on the other way, the lowest microhardness values were achieved during cutting with the cutting speed $\mathrm{v}_{\mathrm{c}} 1131.0 \mathrm{~m} \cdot \mathrm{min}^{-1}$ (feed rate $\mathrm{v}_{\mathrm{f}} 20 \mathrm{~m} \cdot \mathrm{min}^{-1}$ ).

\section{CONCLUSION}

The results of the experiments imply that introduction of high feed milling will result in significant time savings of the milling, and additional finishing of the machined surface will be eliminated with concurrent drop of production costs.

This experiment brings advances in cutting technology and helps to manufacturing companies lower costs, shorten delivery times, high quality parts and so on.

Similar results were achieved also in the works (Danišová \& Majerík, 2009), (Dobránsky \& Mandulák 2008) and (Ružarovský, Velišek \& Košt'ál, 2008) in the frame of design and planed experiments in the manufacturing of mechanical engineering.

\section{ACKNOWLEDGEMENTS}

Experimental part of the contribution was performed in cooperation with the Institute of Mechanical Technology of Poznan University of Technology in Poland. Sincere thanks belong especially to professor Stanislaw LEGUTKA, DSc., $\mathrm{PhD}$., MSc., Eng. for allowing us to perform experiments in the laboratories of the Institute of Mechanical Technology and active assistance in practical execution of the experiments.

This contribution is based on an experiment performed by the Department of Machining and Assembly of the Faculty of Mechanical Engineering of VŠB-Technical University of Ostrava.

The realization of experimental work and measuring of microhardness of surface layer was supported by Students Grant Competition of the Ministry of Education, Youth and Sports and Faculty of Mechanical Engineering VŠB-Technical University of Ostrava.

\section{REFERENCES}

Danišová, N. \& Majerík, J. (2009). Diagram of automated grippers changing in the intelligent manufacturing cell. In: Vedecké práce MtF STU v Bratislave so sidlom v Trnave. Research papers Faculty of Materials Science and Technology Slovak University of Technology in Trnava. No. 26 (2009), p. 7-12. ISSN 1336-1589

Dobránsky, J. \& Mandulák, D. (2008). Design of planed experiments to appraisal of quality parameters by injection moulding. In: Mechanical Engineering : Annals of the University of Petrosani. vol. 10 (37) (2008), p. 53-58. ISSN 1454-9166

Erdel, Bert P. (2003). High - speed machining. Deaborn, Michigan : Society of Manufacturing Engineering, 2003. p. 250. ISBN 0-87263-649-6

Grzesik, W. (2008). Advanced Machining Processes of Metallic Materials, Theory, Modelling and Aplications. 2008. Oxford, United of Kingdom, p. 448. ISBN 978-0-08044534-2

Ružarovský, R. \& Velišek, K. \& Košt’ál, P. (2008). Design and planning of manufacturing and assembly systems. In: Scientific Bulletin. Vol. XXII (2008). Baia Mare : North University of Baia Mare, Romania, p. 413-418. ISSN 12243264

Shaw, Milton C. (2005). Metal Cutting Principles. 2nd edition. New York : Oxford University Press, 2005. p. 651. ISBN 019-514206-3

Skopeček, T. \& Vodička, J. (2005) Fundamentals of high speed cutting - HSC. $1^{\text {st }}$ edition. Pilsen: University of West Bohemia Press, 2005. p. 150. ISBN 80-7043-410-4 